\title{
Engaging university students
}

\author{
LYNDEL KING*
}

\begin{abstract}
Resumo
O público mais difícil de conquistar para um museu universitário é, por vezes, aquele que se encontra mais próximo - os estudantes. Com efeito, o tempo dos 50.000 estudantes da Universidade do Minnesota é escasso: para além do estudo e das aulas, muitos ainda trabalham e vivem em grandes áreas urbanas vizinhas. Para além disso, alguns estudos revelam que a maioria não é visitante habitual de museus à entrada na universidade. O Museu de Arte Frederick R. Weisman é visitado anualmente por cerca de 150.000 estudantes e pretende atingir todos os estudantes e não apenas os de arte. Os seus programas educacionais incluem a colaboração com organizações e associações de estudantes, a promoção de visitas e aulas das mais diversas disciplinas nas suas instalações, o convite a estudantes para eventos sociais que passem igualmente por contemplar obras de arte, a colaboração com departamentos a priori distantes (como os de engenharia química e de ciências dos materiais) para a realização de conferências e outras actividades (sobre a elegância na arte e na ciência, por exemplo) e ainda a oferta de prémios a estudos sobre arte desenvolvidos por estudantes. Apesar do êxito inicial do Museu se dever, sem dúvida, ao magnífico edifício concebido por Frank Gehry (1993), um sucesso sustentado passa necessariamente pelos programas e exposições que este concebe e implementa. Este artigo descreve algumas iniciativas que um museu universitário de arte pode desenvolver no sentido de alargar o âmbito dos seu público estudantil, em particular a estudantes que não são de arte.
\end{abstract}

\begin{abstract}
The hardest audience for university museums to engage is often the one closest at hand - university students. There is much competition for the time of our 50,000 students. Most work, at least part time, and they live in a large urban area. Studies show that most have not regularly attended a museum before they enter university. Our attendance is 150,000 annually; our mission is to educate all students, not just those studying art or related disciplines. Ways to engage students include collaborating with student organizations; engaging faculty from diverse disciplines to make assignments and hold classes in the museum; inviting students to social events (such as dances for new students to meet each other) that also involve looking at art; collaborating with unlikely departments (such as chemical engineering and materials sciences) to sponsor lectures (on topics such as elegance in the arts and sciences) and other programs; and offering cash prizes for student essays about art on display. While our initial success might have been the attraction of our new Frank Gehry designed facility (1993) continued success involves programs. My paper will describe ways for university museums to widen student audiences, particularly from non-art students.
\end{abstract}

I am the director of an art museum in the middle of the United States at a very large state universitynearly 50,000 students and another 12,000 faculty and staff in an urban area of about 3.5 million. We have a collection of about 17,000 objects. On our campus we also have a museum of natural history and a small costume and textile design museum. In our city we have two large art museums, a large

\footnotetext{
* Lyndel King is Director and Chief Curator of the Frederick R. Weisman Art Museum. Address: The Frederick R. Weisman Art Museum, University of Minnesota, 333 East River Road, Minneapolis MN 55455, USA. E-mail: kingx001@umn.edu.
} 
science museum, and a large historical museum as well as other small-specialized museums. In 1993 our Museum, named the Frederick R. Weisman Art Museum after one of our major donors, moved to a building designed by Frank Gehry - his first art museum - before the Guggenheim at Bilbao, Spain, even! Our Museum was constructed entirely with gifts - though the university owns it, no government funds were used to build it (fig. 1). The University provides about half our annual expenses the other half comes from earned income and fundraising. Our annual attendance last year was about 150,000, about half of those were University students.

Many university art museums in the United States such as ours, evolved out of a populist notion that education must be available to all citizens, and an opportunity to experience art is part of education so it is the responsibility of the university to offer and support that opportunity. Often, as in our case, the art museum came before any significant art collection.

I am a passionate about university museums because I am a convert, and you know that in religious matters converts are the worst! I grew up in a very small, isolated town in the Midwest. I never set foot in a museum of any kind until I went to university. I took an undergraduate degree in microbiology and worked for some years as a chemist and in a virology

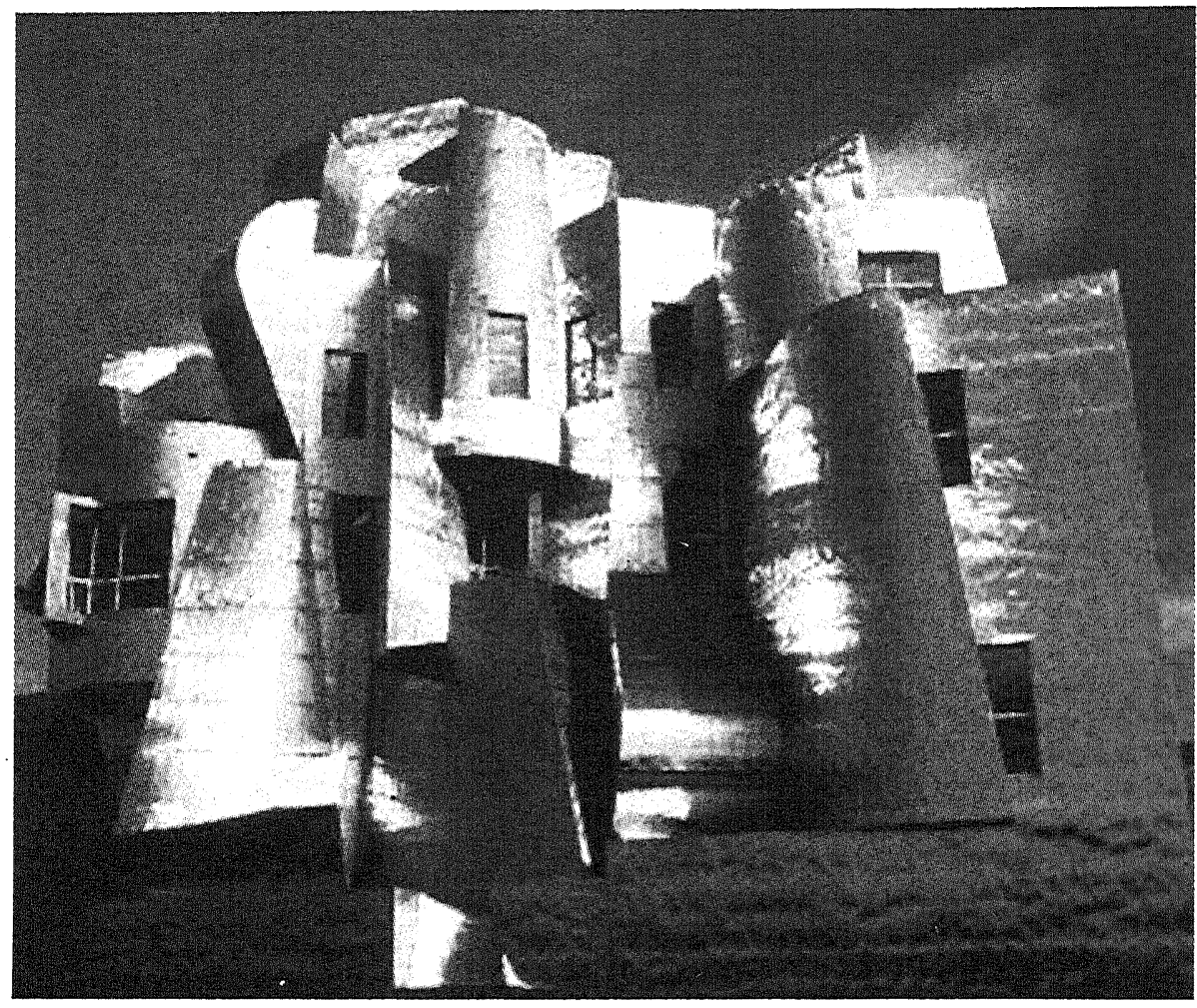

Fig. 1 - The Frederick R. Weisman Art Museum at the University of Minnesota was designed by architect Frank O. Gehry. The University of Minnesota's Art Museum has become a Twin Cities landmark (Photo and copyright by Don F. Wong). 
laboratory. But because of my experience in a university art museum, I returned to university for a Ph.D. in art history.

We, at university museums, have an enormous possibility to change the lives of our students, particularly in America where people aren't so cultured as in Europe. I say that on our campus that I just want students to have the same opportunity to learn to love art, as they have to learn to love football. Not everyone will turn out to be an art fan, not everyone will be a football fan, but they should have an equal opportunity to learn about both!

In the United States museums generally are moving away from the curatorial point of view - the idea that museums existed first of all to protect their collections and create knowledge about them. One of our colleagues, Steven Weil, who was deputy director of the Hirschhorn Museum in Washington, D.C. for many years, and who teaches and publishes widely about museums, has described this shift as 'from being about something to being for someone'.

The shift is away from the idea that it is curatorial research that decides what we offer to the idea that we need to try to determine what our audiences want to know and in addition, determine ways to reach people with different learning styles. American museums generally have moved to a marketing approach that is, instead of deciding what is good for our audiences and trying to sell it to them, we first find out what they want to buy - or learn - and then teach it to them in the way they can best learn it. This can lead to an approach like that of our major science museum in town, which put up large outdoor billboards proclaiming "Which is more stimulating at the Science Museum, the exhibits or the espresso bar"? Or it leads to our major art museum presenting an exhibit of memorabilia from the popular movies Star Wars because surveys had told them this is something boys ages 12-18 wanted to see and this was a targeted new audience for them.

If we at the University embrace the popular marketing approach, we should ask our audience that is our students - what they want. We do. They tell us they want us to be more "with it." They told us last year that much of what we showed was boring (this includes the retrospective and scholarly catalogue we did on American modernist painter Marsden Hartley and the exhibition curated by archaeology and architecture professors on monasteries). Students tell us they want to see only 'new media' art, not those old fashioned paintings and sculptures. They want buttons to push and a quick succession of moving images, the kind they see on music videos.

How far should we take this new marketing approach that is so popular in the United States is a question we discuss often. How do we balance scholarship, collections, and popularity? How do we advance the ideas of our curators who have spent their lives studying our collections? How do we show those boring old paintings and sculptures - in addition to new videos - and still get students to come to the Museum? I'm not yet willing to abdicate our expertise as museum professionals but the question is how do we keep this and still increase our student audiences.

As I am sure you all know, students are sometimes our most critical and hardest audiences to attract. Almost all our students have jobs; some have nearly full-time jobs. They have a very small amount of time left over from classes and jobs so we cannot leave their attendance to chance. Because we are a large state university with relatively low tuition, we have many 
students from families with lower incomes. We know from surveys that most of the students at. our University do not have going to an art museum as a normal activity in their family.

I will talk about two basic approaches that have worked for us. I know the examples I give may not work for you, but they are just examples intended to stimulate the creativity that you all have. These two basic approaches are: i) viewing the entire faculty of the University as part of the Museum staff; and ii) presenting programs that give students a sense of ownership in the Museum - an emotional connection that this is a place for them.

One of the most successful ways we expand our student audience is to work with professors to make going to the Museum part of a class assignment. This is not something we leave to professors. Our Museum staff takes the initiative in making suggestions to faculty and usually they are receptive.

Of course, we work closely with professors in disciplines such as art, art history, and architecture. Professors in those disciplines assign students to draw in the Museum and to look at exhibitions. We work with seminars in which students present a small research exhibition, usually drawn from our collection. These seminars are not only for art history students. Student curated exhibits have included Chinese calligraphy, prints and drawings of women at the turn of the $20^{\text {th }}$ century, and artist designed dinnerware, among others. This year we worked with artist Mark Dion to present an exhibit celebrating our University's $150^{\text {th }}$ anniversary. Eight students worked with the artist and our staff to organize more than 750 objects from 54 collections at the University in the style of a Renaissance Cabinet of Curiosities. Next year we are working with the director of our
Center for Holocaust and Genocide Studies on an exhibition of artist designed bookplates from a collection of a Czech Jewish family.

Using seminars and faculty to involve students is not a new idea, I know, but what I would emphasize is that professors from a wide variety of disciplines have been receptive to working with the Museum. But they do not come to us; we have to go to them.

We have attracted students from engineering by forming a partnership with our University's Institute of Technology. With professors from this area we formed an ad hoc brainstorming group on the concept of elegance in the arts and sciences. First a student intern interviewed faculty across the University about what elegance meant in their disciplines. We summarized the interviews and started a faculty discussion group. After a few meetings we decided to jointly sponsor a lecture series bringing speakers from across the country. The Institute of Technology, being considerably richer than the Museum, paid for the speakers and the Museum provided the publicity and the space. Engineering students were required to attend the lecture series and after every lecture, a selected group of students and faculty members from the arts and sciences were invited to a dinner at the Museum with the guest speaker.

We have a nice small lecture hall and a place for receptions, and we provide this free to University departments for public lectures. These bring students to the Museum who might not otherwise come, and during the break they peruse the galleries and we hope, return.

Several dance performances based on works of art have been choreographed and performed in the Museum galleries by students as a part of class 
assignments. Our staff provided close supervision during rehearsals to make sure that the dances would not harm works of art - we had many conversations about why throwing people into the air at sculptures or jumping off walls in front of paintings could not be done. However, after a few experiences, the dance faculty agreed that the positive results of having a real physical object to inspire the choreographers and the performers outweighed the restrictions we placed on their performances. Here is a noontime 'art' exercise program we organized without physical education faculty in conjunction with an exhibition of contemporary art called 'Through the Body', which was about contemporary artists' use of the body as the subject for their art.

One of our most successful and long term programs is a contest in partnership with our University's creative writing program. All students in beginning level creative writing classes are assigned to write about a work of art at the Museum. At the end of the semester, students may submit their writing to a jury. We offer cash prizes, underwritten by the University's Office for Student Affairs. We post the poems and excerpts from the essays beside the work of art for a year and publish them in our newsletter. The results are always interesting and sometimes remarkable. We are now working with our scientists in genomics towards an art exhibition and a symposium that will combine artists, scientists, and ethicists.

We also pay careful attention to our exhibit texts to make them concise and free of art historical jargon. We run them through our word processing program to check the reading level and if it is higher than first year college student level, we edit them again.

To try to make students feel that the Museum is their

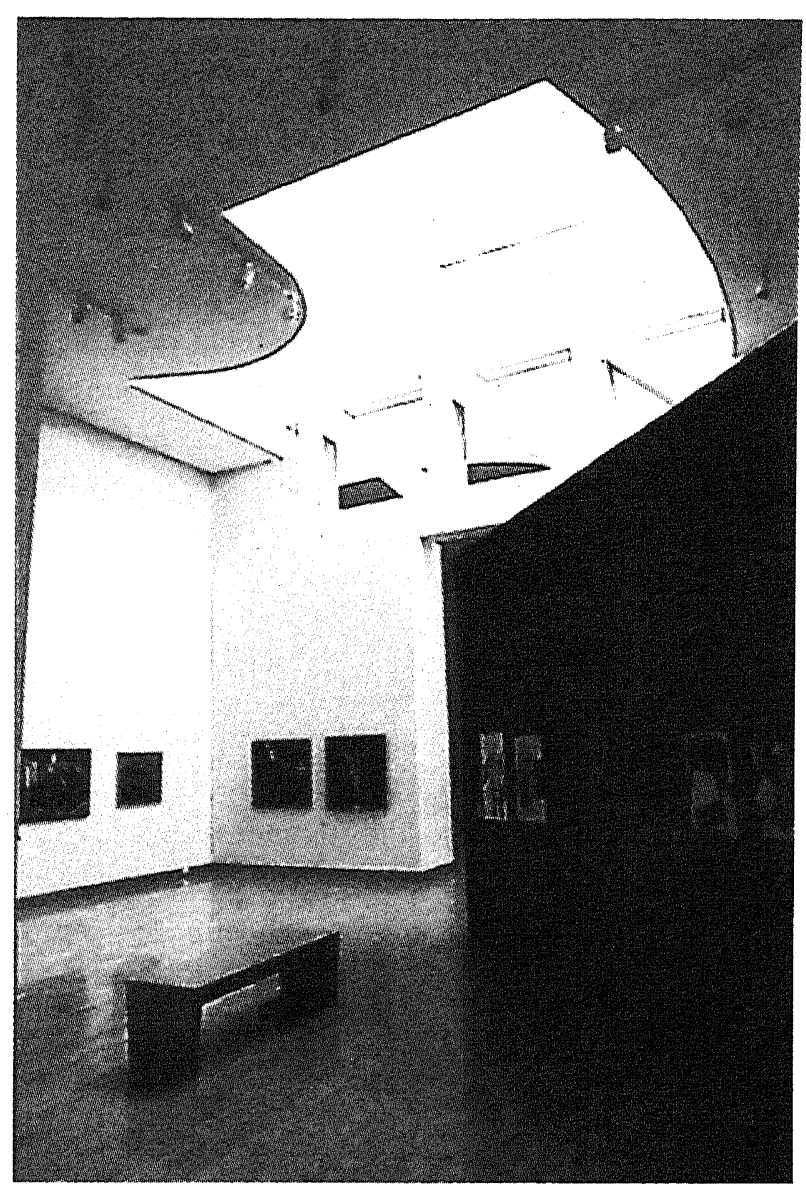

Fig. 2 - The Museum contains 17,000 pieces of art in its permanent collection and holds an internationally significant collection of American art from the first half of the 20th century, including the world's largest collection of work by Marsden Hartley, Alfred $\mathrm{H}$. Maurer and B.J.O. Nordfelt. The Museum also has strong collections of Asian, American, European, and Native American ceramics, as well as Korean furniture (Photo by Robert Fogt (C) Weisman Art Museum).

place, we use them as mentors and teachers for the programs we offer for elementary and high school students. For example, each summer we give a workshop to introduce secondary school students to architecture. Our University's architecture school contributes money to the program because it helps 
them identify good potential students. A faculty member from the architecture school directs the program and University architecture students get academic credit for supervising the younger students.

University theater students present performances based on our exhibitions - two students researched, wrote, and gave a performance based on themes in an exhibition of African American artist Jacob Lawrence. They received credit in the theater department for their work and their performance at the Museum won them internships at our major city theatre the next year.

Students from our music school play for our programs for families with young children. We present noontime concerts during the summer using students from a University music camp. Graduate students in art history offer courses at the Museum for senior citizens. And, students from everywhere helped create a museum art car we drove in a school parade. The car was donated by one of our community volunteers then covered in a design with different colored beans. It had the Museum logo on its hood.

We also try to meet students where they live and play. Yes, we have dances at the Museum. We knew that we wanted to do these kinds of things when we designed the building so we have a large lobby space and our small auditorium has a flat floor rather than fixed seats - we move chairs in and out for lectures. 'Funk at the Fred', our dance during welcome week - a time for new student orientation - usually attracts between 2,000 and 3,000 first year students. We have two other large dances during the year that attract between 1,000 and 2500 students each. We call these 'Dr. Date and the Love Nurses Mixers'. Dr. Date writes an advice column in our student newspaper and the newspaper helps sponsor the dance. The first year we had these dances we were very worried. About 11 PM I came downstairs to see how everything was going and our curator rushed up to me at the elevator door. "Oh my God," she shrieked, "the students are in the galleries!" My mind raced. "What are they doing," I thought, "writing on the paintings with lipstick, slam dancing into the sculptures?" Disasters flashed before my eyes in that moment she paused. "And," she continued, "They're reading the labels!" Of course, we don't think we're going to convert any art history majors at these events, but we do think that we may convince some students that it is Ok to go into an art museum, that it isn't intimidating, and they might want to come back some time later. And, they do.

Sometimes it seems that we are redefining ourselves every moment. How can we encourage real scholarship and contribute to the academic enterprise, protect our collection, raise half our budget every year, link the University to the community and attract University students in the process. We must be more creative, more energetic, and more enterprising. To increase our student audiences we must view the entire University faculty - not just faculty in our discipline - as possible partners and we must make students think that the museum is their place. Just presenting exhibitions that curators think are wonderful is no longer good enough. 